Article

\title{
Comparison of Microwave-Assisted and Conventional Hydrodistillation in the Extraction of Essential Oils from Mango (Mangifera indica L.) Flowers
}

\author{
Hong-Wu Wang, Yan-Qing Liu *, Shou-Lian Wei, Zi-Jun Yan and Kuan Lu
}

School of Chemistry \& Chemical Engineering, Zhaoqing University, Zhaoqing 526061, China

* Author to whom correspondence should be addressed; E-Mail: yqliucn@hotmail.com.

Received: 27 August 2010; in revised form: 27 September 2010 / Accepted: 11 October 2010 /

Published: 29 October 2010

\begin{abstract}
Microwave-assisted hydrodistillation (MAHD) is an advanced hydrodistillation (HD) technique, in which a microwave oven is used in the extraction process. MAHD and HD methods have been compared and evaluated for their effectiveness in the isolation of essential oils from fresh mango (Mangifera indica L.) flowers. MAHD offers important advantages over HD in terms of energy savings and extraction time (75 min against $4 \mathrm{~h}$ ). The composition of the extracted essential oils was investigated by GC-FID and GC-MS. Results indicate that the use of microwave irradiation did not adversely influence the composition of the essential oils. MAHD was also found to be a green technology.
\end{abstract}

Keywords: Mangifera indica L.; essential oil; microwave-assisted hydrodistillation; GC-MS

\section{Introduction}

Mango (Mangifera indica L.) is one of the most important and popular tropical fruits, due mainly to its delicious flavor and nutritional value [1]. In various parts of the world, several hundreds of cultivars that have markedly varying flavor characteristics are grown [2]. Thus, numerous studies have been conducted on mango flavor composition. The volatile constituents of mango have also been extensively investigated. In past decades, more than 300 volatile components have been identified from several varieties of mango [3-14]. These compounds are free forms or glycosidically bound compounds [15-19]. In these varieties, considerable variation in volatile composition is observed.

The techniques for the extraction of volatile oils have also been reported to cause variations in the volatile compounds of samples [20]. The techniques used to extract volatile compounds from mango 
include solvent extraction [15], vacuum steam distillation followed by solvent extraction [21], simultaneous distillation-extraction [1,5,6], static headspace [22-23], solid-phase extraction [16], headspace solid-phase microextraction [19], and so on. The studies of Larrauri et al. [24] showed that mango peel fibers can be included in high dietary fiber diets because the fibers have beneficial health effects.

HD is the most common approach to the extraction of essential oils from medicinal herbs and plants, as described in various pharmacopoeias, such as the 2005 Chinese Pharmacopoeia [25]. Conventional methods present several drawbacks such as long extraction times, potential loss of volatile constituents, high energy use, and so on. Thus, developing an alternative extraction technique that is rapid, sensitive, safe, and energy-efficient is highly desirable. New extraction techniques have been applied to shorten extraction time, reduce organic solvent consumption, improve extraction yield, enhance extract quality, prevent pollution, and reduce sample preparation costs; these techniques include microwave assisted extraction (MAE), supercritical fluid extraction (SFE), and ultrasonic assisted extraction (UAE) [26-27]. Some recently published studies have successfully used a microwave oven as a heater in the extraction of essential oils from medicinal plants and herbs [1,2830]. To take advantage of microwave heating with traditional HD, MAHD was subsequently developed and used for the extraction of essential oils from Dictyopteris membranacea, Salvia rosifolia Sm., Thymus vulgaris L, Cuminum cyminum L., and Zanthoxylum bungeanum Maxim [20,27-29].

To the best of the authors' knowledge, however, no data on the MAHD of volatiles in mango flowers have been reported. Therefore, the objective of the present work is to investigate the potential of MAHD for extracting essential oils from mango flowers. The compositions of the essential oils extracted by MAHD and HD were analyzed by GC-FID and GC-MS. The extraction time, volatile components, and extraction yield of MAHD were also compared with those of HD.

\section{Results and Discussion}

Essential oils from mango flowers were obtained by MAHD and HD. The oils were subsequently analyzed by GC-FID and GC-MS. The identities of the extracted essential oils from both methods are listed in Table 1.

Table 1. Constituents of essential oils from the flowers of mango extracted with MAHD and HD.

\begin{tabular}{|c|c|c|c|c|c|c|}
\hline \multirow{2}{*}{$\begin{array}{c}\text { Peak } \\
\text { number }\end{array}$} & \multirow{2}{*}{ Compound } & \multirow{2}{*}{ Formula } & \multirow{2}{*}{ RI } & \multicolumn{2}{|c|}{$\%$ Composition } & \multirow{2}{*}{$\begin{array}{c}\text { Methods of } \\
\text { Identification }\end{array}$} \\
\hline & & & & MAHD & HD & \\
\hline 1 & trans-3-Hexen-1-ol & $\mathrm{C}_{6} \mathrm{H}_{12} \mathrm{O}$ & 858 & 0.09 & 0.14 & $\mathrm{RI}, \mathrm{MS}^{\mathrm{b}}$ \\
\hline 2 & 1-Hexanol & $\mathrm{C}_{6} \mathrm{H}_{14} \mathrm{O}$ & 878 & 0.06 & 0.10 & RI, MS \\
\hline 3 & Heptanal & $\mathrm{C}_{7} \mathrm{H}_{14} \mathrm{O}$ & 903 & 0.05 & 0.06 & RI, MS \\
\hline 4 & $\alpha$-Pinene & $\mathrm{C}_{10} \mathrm{H}_{16}$ & 932 & 3.47 & 2.39 & RI, MS, CoI \\
\hline 5 & Camphene & $\mathrm{C}_{10} \mathrm{H}_{16}$ & 945 & 0.40 & 0.27 & RI, MS \\
\hline 6 & Sabinene & $\mathrm{C}_{10} \mathrm{H}_{16}$ & 975 & 0.14 & 0.07 & RI, MS \\
\hline 7 & Myrcene & $\mathrm{C}_{10} \mathrm{H}_{16}$ & 978 & 2.23 & 2.11 & RI, MS \\
\hline
\end{tabular}


Table 1. Cont.

\begin{tabular}{|c|c|c|c|c|c|c|}
\hline 8 & $\beta$-Pinene & $\mathrm{C}_{10} \mathrm{H}_{16}$ & 979 & 1.27 & 0.95 & RI, MS \\
\hline 9 & 2-Carene & $\mathrm{C}_{10} \mathrm{H}_{16}$ & 995 & 1.04 & 1.01 & RI, MS \\
\hline 10 & $\alpha$-Phellandrene & $\mathrm{C}_{10} \mathrm{H}_{16}$ & 1001 & 1.68 & 1.76 & RI, MS \\
\hline 11 & $\delta$-3-Carene & $\mathrm{C}_{10} \mathrm{H}_{16}$ & 1011 & 7.72 & 8.17 & RI, MS \\
\hline 12 & $\alpha$-Terpinene & $\mathrm{C}_{10} \mathrm{H}_{16}$ & 1017 & 4.64 & 5.31 & RI, MS \\
\hline 13 & o-Cymene & $\mathrm{C}_{10} \mathrm{H}_{14}$ & 1022 & 0.88 & $-^{\mathrm{a}}$ & RI, MS \\
\hline 14 & p-Cymene & $\mathrm{C}_{10} \mathrm{H}_{14}$ & 1026 & - & 0.34 & RI, MS \\
\hline 15 & Limonene & $\mathrm{C}_{10} \mathrm{H}_{16}$ & 1029 & 5.22 & 5.39 & RI, MS \\
\hline 16 & (Z)- $\beta$-Ocimene & $\mathrm{C}_{10} \mathrm{H}_{16}$ & 1040 & 1.10 & 1.25 & RI, MS \\
\hline 17 & (E)- $\beta$-Ocimene & $\mathrm{C}_{10} \mathrm{H}_{16}$ & 1050 & 0.25 & 0.23 & RI, MS \\
\hline 18 & $\gamma$-Terpinene & $\mathrm{C}_{10} \mathrm{H}_{16}$ & 1059 & 0.69 & 0.91 & RI, MS \\
\hline 19 & $(E)$-Linalool oxide & $\mathrm{C}_{10} \mathrm{H}_{18} \mathrm{O}_{2}$ & 1070 & 0.06 & 0.25 & RI, MS, CoI \\
\hline 20 & Terpinolene & $\mathrm{C}_{10} \mathrm{H}_{16}$ & 1084 & 43.17 & 50.16 & RI, MS \\
\hline 21 & Thujol & $\mathrm{C}_{10} \mathrm{H}_{18} \mathrm{O}$ & 1095 & 0.43 & 0.06 & RI, MS \\
\hline 22 & Linalool & $\mathrm{C}_{10} \mathrm{H}_{18} \mathrm{O}$ & 1100 & 0.48 & 0.63 & RI, MS \\
\hline 23 & Hotrienol & $\mathrm{C}_{10} \mathrm{H}_{16} \mathrm{O}$ & 1101 & 0.71 & 1.09 & RI, MS \\
\hline 24 & $\begin{array}{l}\text { 4-Isopropyl-1-methyl-2- } \\
\text { cylohexen-1-ol }\end{array}$ & $\mathrm{C}_{10} \mathrm{H}_{18} \mathrm{O}$ & 1117 & - & 0.13 & RI, MS \\
\hline 25 & $\begin{array}{l}(3 E, 5 E)-2,6 \text {-Dimethyl- } \\
\text { 1,3,5,7-octatetraene }\end{array}$ & $\mathrm{C}_{10} \mathrm{H}_{14}$ & 1134 & 0.22 & 0.24 & RI, MS, CoI \\
\hline 26 & cis-Verbenol & $\mathrm{C}_{10} \mathrm{H}_{16} \mathrm{O}$ & 1140 & 0.82 & - & RI, MS \\
\hline 27 & (Z)-2-Nonenal & $\mathrm{C}_{9} \mathrm{H}_{16} \mathrm{O}$ & 1145 & 0.06 & 0.05 & RI, MS \\
\hline 28 & 2-Ethylcyclohexanone & $\mathrm{C}_{8} \mathrm{H}_{14} \mathrm{O}$ & 1158 & 0.46 & - & RI, MS \\
\hline 29 & $p$-Mentha-1,5-dien-8-ol & $\mathrm{C}_{10} \mathrm{H}_{16} \mathrm{O}$ & 1159 & 0.06 & - & RI, MS, CoI \\
\hline 30 & Terpinen-4-ol & $\mathrm{C}_{10} \mathrm{H}_{18} \mathrm{O}$ & 1178 & 0.85 & 0.82 & RI, MS \\
\hline 31 & Nerol oxide & $\mathrm{C}_{10} \mathrm{H}_{16} \mathrm{O}$ & 1162 & 0.07 & 0.11 & RI, MS \\
\hline 32 & p-Cymen-8-ol & $\mathrm{C}_{10} \mathrm{H}_{14} \mathrm{O}$ & 1182 & 4.04 & 0.33 & RI, MS \\
\hline 33 & $\alpha$-Terpineol & $\mathrm{C}_{10} \mathrm{H}_{18} \mathrm{O}$ & 1190 & 0.75 & 0.97 & RI, MS \\
\hline 34 & 2-Methylisoborneol & $\mathrm{C}_{11} \mathrm{H}_{20} \mathrm{O}$ & 1197 & 1.13 & - & RI, MS \\
\hline 35 & $\gamma$-Terpineol & $\mathrm{C}_{10} \mathrm{H}_{18} \mathrm{O}$ & 1199 & 0.15 & 0.18 & RI, MS \\
\hline 36 & Nerol & $\mathrm{C}_{10} \mathrm{H}_{18} \mathrm{O}$ & 1233 & 0.09 & 0.11 & RI, MS \\
\hline 37 & Geraniol & $\mathrm{C}_{10} \mathrm{H}_{18} \mathrm{O}$ & 1255 & 0.05 & 0.06 & RI, MS \\
\hline 38 & trans-3-Caren-2-ol & $\mathrm{C}_{10} \mathrm{H}_{16} \mathrm{O}$ & 1272 & 0.18 & - & RI, MS \\
\hline 39 & $p$-Ethylguaiacol & $\mathrm{C}_{9} \mathrm{H}_{12} \mathrm{O}_{2}$ & 1287 & 0.74 & - & RI, MS \\
\hline 40 & $\alpha$-Copaene & $\mathrm{C}_{15} \mathrm{H}_{24}$ & 1375 & 0.24 & 0.25 & RI, MS \\
\hline 41 & $\beta$-Elemene & $\mathrm{C}_{15} \mathrm{H}_{24}$ & 1391 & 0.05 & 0.11 & RI, MS \\
\hline 42 & Methyl eugenol & $\mathrm{C}_{11} \mathrm{H}_{14} \mathrm{O}_{2}$ & 1401 & 0.04 & 0.05 & RI, MS, CoI \\
\hline 43 & $\alpha$-Gurjunene & $\mathrm{C}_{15} \mathrm{H}_{24}$ & 1412 & 1.17 & 1.50 & RI, MS \\
\hline 44 & $\beta$-Caryophyllene & $\mathrm{C}_{15} \mathrm{H}_{24}$ & 1420 & 1.34 & 1.84 & RI, MS \\
\hline 45 & Carvone hydrate & $\mathrm{C}_{10} \mathrm{H}_{16} \mathrm{O}_{2}$ & 1424 & 0.75 & 0.06 & RI, MS \\
\hline
\end{tabular}


Table 1. Cont.

\begin{tabular}{|c|c|c|c|c|c|c|}
\hline 46 & Aromadendrene & $\mathrm{C}_{15} \mathrm{H}_{24}$ & 1443 & 0.15 & 0.17 & RI, MS \\
\hline 47 & $\alpha$-Guaiene & $\mathrm{C}_{15} \mathrm{H}_{24}$ & 1453 & 0.28 & 1.29 & RI, MS \\
\hline 48 & $\alpha$-Humulene & $\mathrm{C}_{15} \mathrm{H}_{24}$ & 1453 & 0.71 & 0.82 & RI, MS \\
\hline 49 & Alloaromadendrene & $\mathrm{C}_{15} \mathrm{H}_{24}$ & 1461 & 0.16 & - & RI, MS \\
\hline 50 & $\gamma$-Muurolene & $\mathrm{C}_{15} \mathrm{H}_{24}$ & 1475 & 0.28 & - & RI, MS \\
\hline 51 & $\beta$-Selinene & $\mathrm{C}_{15} \mathrm{H}_{24}$ & 1482 & 3.01 & 3.75 & RI, MS \\
\hline 52 & $\alpha$-Amorphene & $\mathrm{C}_{15} \mathrm{H}_{24}$ & 1484 & - & 0.37 & RI, MS \\
\hline 53 & Germacrene D & $\mathrm{C}_{15} \mathrm{H}_{24}$ & 1487 & 0.77 & 0.86 & RI, MS \\
\hline 54 & $\alpha$-Muurolene & $\mathrm{C}_{15} \mathrm{H}_{24}$ & 1499 & 0.27 & 0.37 & RI, MS \\
\hline 55 & $\delta$-Cadinene & $\mathrm{C}_{15} \mathrm{H}_{24}$ & 1519 & 0.30 & 0.46 & RI, MS \\
\hline 56 & Epiglobulol & $\mathrm{C}_{15} \mathrm{H}_{26} \mathrm{O}$ & 1532 & 0.18 & 0.68 & RI, MS \\
\hline 57 & $\delta$-Guaiene & $\mathrm{C}_{15} \mathrm{H}_{24}$ & 1526 & 0.51 & 0.59 & RI, MS, CoI \\
\hline 58 & Ledol & $\mathrm{C}_{15} \mathrm{H}_{26} \mathrm{O}$ & 1552 & - & 0.11 & RI, MS \\
\hline 59 & Guaia-3,9-diene & $\mathrm{C}_{15} \mathrm{H}_{24}$ & 1556 & 0.62 & 0.12 & RI, MS \\
\hline 60 & Caryophyllene oxide & $\mathrm{C}_{15} \mathrm{H}_{24} \mathrm{O}$ & 1573 & 0.12 & - & RI, MS \\
\hline 61 & $\alpha$-Cadinol & $\mathrm{C}_{15} \mathrm{H}_{26} \mathrm{O}$ & 1653 & - & 0.29 & RI, MS \\
\hline \multicolumn{2}{|l|}{ Total } & & & 96.40 & 99.34 & \\
\hline \multicolumn{2}{|c|}{ Monoterpene hydrocarbons } & & & 74.12 & 80.56 & \\
\hline \multicolumn{2}{|c|}{ Oxygenated monoterpenes } & & & 9.49 & 4.8 & \\
\hline \multicolumn{2}{|c|}{ Sesquiterpene hydrocarbons } & & & 9.86 & 12.5 & \\
\hline \multicolumn{2}{|c|}{ Oxygenated sesquiterpenes } & & & 0.30 & 1.08 & \\
\hline \multicolumn{2}{|l|}{ Others $^{\mathrm{c}}$} & & & 2.63 & 0.40 & \\
\hline \multicolumn{2}{|c|}{ Oil yield (w/w\%) } & & & 0.16 & 0.11 & \\
\hline \multicolumn{2}{|l|}{ Types } & & & 56 & 51 & \\
\hline
\end{tabular}

a absent. RI, retention indices relative to $\mathrm{C}_{6}-\mathrm{C}_{24}$ n-alkanes on the Rtx-5ms column; ${ }^{\mathrm{b}} \mathrm{MS}$, mass spectrum; CoI, coinjection with an authentic sample. ${ }^{\mathrm{c}}$ Others: hydrocarbons such as alkanes and esters.

The yields of the oils $(\mathrm{w} / \mathrm{w} \%)$ at extraction were in the following order: MAHD $(0.16 \%)>\mathrm{HD}$ $(0.11 \%)$. In total, 51 and 56 constituents were identified and quantified in MAHD and HD extraction, respectively (Table 1).

The results of GC-MS analyses show that a major portion of the mango flowers is composed of monoterpene hydrocarbons (Table 1). As for the oil extracted by MAHD, the main constituents were terpinolene $(43.17 \%), \delta$-3-carene $(7.72 \%)$, limonene $(5.22 \%), \alpha$-terpinene $(4.64 \%)$, and $p$-cymen-8-ol (4.04\%). The main content in the essential oil was monoterpene hydrocarbons $(74.12 \%)$, followed by sesquiterpene hydrocarbons (9.86\%), oxygenated monoterpenes $(9.49 \%)$, “others" (2.63\%), and oxygenated sesquiterpenes $(0.30 \%)$, as shown in Table 1 .

In the oil extracted by $\mathrm{HD}$, the main constituents were terpinolene $(50.16 \%), \delta$-3-carene $(8.17 \%)$, limonene $(5.39 \%), \alpha$-terpinene $(5.31 \%)$, and $\beta$-selinene $(3.75 \%)$. The essential oil was composed mainly of monoterpene hydrocarbons $(80.56 \%)$. The percentage of sesquiterpene hydrocarbons, 
oxygenated monoterpenes, oxygenated sesquiterpenes, and hydrocarbons, such as alkanes and esters (classified as "others"), were 12.5\%, 4.80\%, 1.08\%, and 0.4\%, respectively (Table 1).

The constituents of the essential oils extracted by both MAHD and HD were similar. Both essential oils were found to be rich in monoterpene hydrocarbons. terpinolene (compound 20) was the most abundant component in mango essential oil (43.17\% for MAHD and 50.16\% for HD) followed by $p-\delta$ 3 -carene (compound 11), limonene (compound 15), $\alpha$-terpinene (compound 12) and $\beta$-Selinene (compound 51). These results are in good agreement with [8], who reported 20 mango cultivars which were investigated by means of simultaneous distillation-extraction, GC, and GC-MS. The main compounds of essential oil of mango from Kenya were $\alpha$-pinene, $\alpha$-phellandrene, limonene and $p$ cymene [9], while $\alpha$-pinene, sabinene, $\beta$-pinene and limonene were dominant components in the fruit oil of mango from India [10]. The dominant compounds mango leaf oil from Nigeria were $\delta$-3-carene, $\alpha$-gurjunene, $\beta$-selinene and $\beta$-caryophyllene, while fruit peel oil yielded mainly $\delta$-3-carene and $\alpha$ pinene; whereas according reference 12 , the leaf oil of mango form Nigeria possessed a considerable proportion of $\alpha$-gurjunene, $\beta$-selinene, $\beta$-caryophyllene and $\alpha$-humulene.

The appearance, specific gravity, and refractive index of the essential oils extracted with HD and MAHD are provided in Table 2. The specific gravities and refractive indices of the essential oils are similar, with the only difference being that the color of the MAHD essential oils was lighter than that of the HD oils. Thus, MAHD does not present any problems in the extraction of essential oils from mango flowers.

Table 2. Physical properties of essential oils. ${ }^{\mathrm{d}}$

\begin{tabular}{ccc}
\hline Physical properties & MAHD & HD \\
\hline Refractive index & 1.487 & 1.487 \\
Specific gravity & 0.921 & 0.917 \\
Appearance & Pale yellow & Yellow \\
\hline${ }^{\mathrm{d}}$ The refractive index and specific gravity were measured at $20^{\circ} \mathrm{C}$.
\end{tabular}

\section{Experimental}

\subsection{Plant material}

Fresh mango flowers were collected from Southern regions of China on 19 December 2008. The plant was identified by Vice Professor Xiongwei Chen of the College of Life Sciences at Zhaoqing University. Voucher specimens (code number 0826) were deposited at the herbarium of the College of Life Sciences, Zhaoqing University.

\subsection{Isolation of essential oils}

Hydrodistillation was performed according to the method recommended in the Chinese Pharmacopoeia [25]. Fresh mango flowers (500 g) were hydrodistilled for $4 \mathrm{~h}$ using a Clevenger-type apparatus to yield $0.11 \%$ of a yellowish, strong-smelling oil. 
Fresh flowers $(200 \mathrm{~g})$ were hydrodistilled at $800 \mathrm{~W}$ for $75 \mathrm{~min}$ using an adapted microwave distillation apparatus (wp800, Galanz, China), which consists of a microwave oven connected to a Clevenger-type apparatus to yield $0.16 \%$ of a yellowish, strong-smelling oil.

The extracted essential oils were dried over anhydrous sodium sulfate and stored in amber vials at $4{ }^{\circ} \mathrm{C}$ until analysis. The oil was subsequently subjected to GC-FID and GC-MS analyses, and then dissolved in $n$-hexane $(10 \% \mathrm{v} / \mathrm{v})$ before its composition was chromatographically determined.

\subsection{GC and GC-MS analyses}

The mango essential oils were analyzed by GC using a GC-2010 with AOC-20i auto injection system (Shimadzu Ltd., Japan) system and a silica capillary Rtx-5ms column $(30 \mathrm{~m} \times 0.25 \mathrm{~mm}$ i.d.; film thickness, $0.25 \mu \mathrm{m}$ ) with nitrogen at $1 \mathrm{~mL} / \mathrm{min}$. Initial oven temperature was $80{ }^{\circ} \mathrm{C}$ for $3 \mathrm{~min}$, increased to 6 to $150{ }^{\circ} \mathrm{C} / \mathrm{min}$. The temperature was then kept constant at $150{ }^{\circ} \mathrm{C}$ for 16 min and increased to 30 to $200{ }^{\circ} \mathrm{C} / \mathrm{min}$. Subsequently, the temperature was kept constant at $200{ }^{\circ} \mathrm{C}$ for $2 \mathrm{~min}$ and increased to 20 to $240{ }^{\circ} \mathrm{C}$ for $2 \mathrm{~min}$. Injector and detector temperatures were 220 and $280{ }^{\circ} \mathrm{C}$, respectively. The carrier gas was nitrogen (volume, $1.0 \mu \mathrm{L}$ ), injected at a flow rate of $1.0 \mathrm{~mL} / \mathrm{min}$ at constant flow. A sample was injected auto without dilution. The percentages of the constituents were calculated by the electronic integration of the FID peak areas without the use of response factor correction.

GC-MS analyses were performed with a GC-MS QP2010 Plus with AOC-20i auto injection system (Shimadzu Ltd., Japan) system and a silica capillary Rtx-5ms column (30 $\mathrm{m} \times 0.25 \mathrm{~mm}$ i.d.; film thickness, $0.25 \mu \mathrm{m}$ ) with helium. GC oven temperature conditions were as described above. Split flow was adjusted to $50 \mathrm{~mL} / \mathrm{min}$, with an injector temperature of $280{ }^{\circ} \mathrm{C}$. The carrier gas was helium, passed at a flow rate of $1.0 \mathrm{~mL} / \mathrm{min}$. A diluted sample $(1.0 \mu \mathrm{L}, 1 / 10$ in ether $)$ was autoinjected. The mass spectra were recorded at $70 \mathrm{eV}$, and the mass range was $\mathrm{m} / \mathrm{z} 35$ to 425 . The ion source and interface temperatures were 200 and $280^{\circ} \mathrm{C}$, respectively.

\subsection{Identification of components}

The constituents of the essential oils were identified by calculating their retention indices under temperature-programmed conditions for $n$-alkanes $\left(\mathrm{C}_{6}-\mathrm{C}_{24}\right)$ and oils on an Rtx-5ms column under the same chromatographic conditions as those in Section 2.3 Individual compounds were identified by comparing their mass spectra with those of the internal reference mass spectra library or with authentic compounds. The compounds were then confirmed by comparing their retention indices with the NIST 2005 GC-MS library data on the GC-MS Adams library spectra [1]. For quantification purposes, the relative area percentages obtained by FID were used without correction factors.

\subsection{Physical properties}

The physical properties, such as appearance, refractive index, specific gravity, and color, of the essential oils extracted (by both methods) from the flowers of the mango samples were determined using the Food Chemical Codex method [31]. The refractive index and specific gravity were measured at $20^{\circ} \mathrm{C}$. 


\section{Conclusions}

Both MAHD and conventional HD are based on the same process as essential oil-water heteroazeotrope. Therefore, oils extracted using both methods must contain a large amount of high volatility compounds, and their chemical composition should, theoretically, be similar. Microwave energy may improve the release of the volatile compounds from the matrix, and high energy flux may enhance their co-distillation. As previously shown by scanning electron microscopy and the cytochemistry of lavender glandular trichomes [32], microwaves cause the glandular walls to quickly rupture, resulting in high extraction efficiency at a shorter time. The results of the GC-MS analyses indicate that no significant differences between the essential oils extracted by MAHD and those extracted by HD were found. MAHD offered substantial advantages over conventional HD. As an excellent alternative to HD, MAHD may have no adverse effects on the composition of extracted essential oils. MAHD is also more environment-friendly than HD. Compared with many solvent extraction techniques, such as Soxhlet, solvent extraction, and accelerated solvent extraction, MAHD is a modern, green, and rapid approach.

\section{References and Notes}

1. MacLeod, A. J.; Snyder, C. H. Volatile components of two cultivars of mango from Florida. J. Agric. Food Chem. 1985, 33, 380-384.

2. Nagy, S.; Shaw, P. E. Tropical and Subtropical Fruits; AVI Publishing: Westport, CT, USA, 1980.

3. MacLeod, A.J.; Snyder, C.H.Volatile components of mango preserved by deep freezing. J. Agric. Food Chem. 1988, 36, 137-139.

4. Gholap, A. S.; Bandyopadhyay, C. Characterisation of green aroma of raw mango (Mangifera indica L.). J. Sci. Food Agric. 1977, 28, 885-888.

5. MacLeod, A. J.; de Troconis, N. G. Volatile flavour components of mango fruit. Phytochemistry 1982, 21, 2523-2526.

6. MacLeod, A. J.; Pieris, N. M. Comparison of the volatile components of some mango cultivars. Phytochemistry 1984, 23, 361-366.

7. Engel, K.-H.; Tressl, R. Studies on the Volatile components of two mango varieties. J. Agric. Food Chem. 1983, 31, 796-801.

8. Pino, J. A.; Mesa, J.; Muñoz, Y.; Martí, M. P.; Marbot, R. Volatile components from mango (Mangifera indica L.) cultivars. J. Agric. Food Chem. 2005, 53, 2213-2223.

9. Alwala, O. J.; W. Wanzala; Inyambukho, R. A.; Osundwa, E. M.; Ndiege, I. O. Characterization and evaluation of repellent effect of essential oil of Mangifera indica L. from Kenya. J. Essent. Oil Bear. Pl. 2010, 13, 85-96.

10. Ansari, S. H., M. Ali, Arturo, V.-N.; Maria Jose P.-A. Characterization of volatile constituents of mango 'Qalmi' (Mangifera indical L.) fruit. J. Essent. Oil Res. 2004, 16, 417-419.

11. Džamic, A. M.; Marin, P. D.; Gbolade, A.A.; Ristic, M.S. Chemical Composition of Mangifera indica Essential Oil From Nigeria. J. Essent. Oil Res. 2010, 22, 123-125. 
12. Ogunwande, I. A.; Saroglou, V.; Skaltsa, E.; Ogunbinu, A. O.; Kubmarawa, D. Constituents of Some Essential Oil Bearing Plants from Nigeria. J. Essent. Oil Res. 2009, 21, 61-66.

13. Pereira, C. G.; Meireles, M. A. A. Evaluation of global yield, composition, antioxidant activity and cost of manufacturing of extracts from lemon verbena (Aloysia triphylla [L'herit.] Britton) and mango (Mangifera indica L.) leaves. J. Food Process Eng. 2007, 30, 150-173.

14. Keita, Y.; Koné, O.; Ly, A. K.; Häkkinen, V. Chemical- and antibacterial-activity studies of some Guinean mango varieties' distillates. C. R. Chim. 2004, 7, 1095-1100.

15. Ollé, D.; Baumes, R.L.; Bayonove, C.L.; Lozano, Y.F.; Sznaper, C.; Brillouet, J.M. Comparison of free and glycosidically linked volatile components from polyembryonic and monoembryonic mango (Mangifera indica L.) cultivars. J. Agric. Food Chem. 1998, 46, 1094-1100.

16. Adedeji, J.; Hartman, T. G.; Lech, J.; Ho, C.-T. Characterization of glycosidically bound aroma compounds in the African mango (Mangifera indica L.). J. Agric. Food Chem. 1992, 40, 659-661.

17. Ansari, S. H.; Ali, M.; Velasco-Neguerela, A.; Pe'rez-Alonso, M. J. Volatile constituents of the fruits of three mango cultivars, Mangifera indica L. J. Essent. Oil Res. 1999, 11, 65-68.

18. Baldwin, E. A.; Burns, J. K.; Kazokas, W.; Brecht, J. K.; Hagenmaier, R. D.; Bender, R. J.; Pesis, E. Effect of two edible coatings with different permeability characteristics on mango (Mangifera indica L.) ripening during storage. Postharvest Biol. Technol. 1999, 17, 215-226.

19. Lalel, H. J. D.; Singh, Z.; Tan S. C. Distribution of aroma volatile compounds in different parts of mango fruit. J. Hortic. Sci. Biotechnol. 2003, 78, 131-138.

20. Hattab, M. E.; Culioli, G.; Piovetti, L.; Chitour, S. E.; Valls, R. Comparison of various extraction methods for identification and determination of volatile metabolites from the brown alga Dictyopteris membranacea. J. Chromatogr. A 2007, 1143, 1-7.

21. Idstein, H.; Schreier, P. Volatile constituents of Alphonso mango (Mangifera indica). Phytochemistry 1985, 24, 2313-2316.

22. Bartley, J. P.; Schwede, A. Volatile flavor components in the headspace of the Australian or 'Bowen' mango. J. Food Sci. 1987, 52, 353-360.

23. Malundo, T. M. M.; Baldwin, E. A.; Moshonas, M. G.; Baker, R. A., Shewfelt, R. L. Method for the rapid headspace analysis of mango (Mangifera indica L.) homogenate volatile constituents and factors affecting quantitative results. J. Agric. Food Chem. 1997, 45, 2187-2194.

24. Larrauri, J.A.; Ruperez, P.; Saura-Calixto, F. Mango peel fibres with antioxidant activity. Zeit. Leben.-Unter. Forsch. A 1997, 205, 39-42.

25. Chinese Pharmacopoeia Committee. Chinese Pharmacopoeia, 9th ed.; China Medical Science and Technology Press: Beijing, China, 2005; Appendix 62.

26. Szentmihályi, K.; Vinkler, P.; Lakatos, B.; Illés,V.; Then, M. Rose hip (Rosa canina L.) oil obtained from waste hip seeds by different extraction methods. Bioresource Technol. 2002, 82, 195-201.

27. Özek, G.; Demirci, F.; Özek, T.; Tabanca, N.; Wedge, D. E.; Khan,S. I.; Başer, K. H. C.; Duran, A.; Hamzaoglu, E. Gas chromatographic-mass spectrometric analysis of volatiles obtained by four different techniques from Salvia rosifolia Sm., and evaluation for biological activity. J. Chromatogr. A 2010, 1217, 741-748. 
28. Golmakani, M.-T.; Rezaei, K.Comparison of microwave-assisted hydrodistillation with the traditional hydrodistillation method in the extraction of essential oils from Thymus vulgaris L. Food Chem. 2008, 109, 925-930.

29. Wang, Z.; Ding, L.; Li, T.; Zhou, X.; Wang, L.; Zhang, H.; Liu, L.; Li, Y.; Liu, Z.; Wang, H.; Zeng, H.; He, H. Improved solvent-free microwave extraction of essential oil from dried Cuminum cyminum L. and Zanthoxylum bungeanum Maxim. J. Chromatogr. A 2006, 1102, 11-17.

30. Lucchesi, M. E.; Chemat, F.; Smadja, J. Solvent free microwave extraction of essential oils from aromatic herbs: Comparison with conventional hydro-distillation. J. Chromatogr. A 2004, 1043, 323-327.

31. Institute of Medicine of the National Academies. Food Chemical Codex, 4th ed., National Academy Press: Washington, DC, USA, 1996; pp. 413-414.

32. Iriti, M.; Colnaghi, G.; Chemat, F.; Smadja, J.; Faoro, F.; Visinoni, F.A. Histo-cytochemistry and scanning electron microscopy of lavender glandular trichomes following conventional and microwave-assisted hydrodistillation of essential oils: a comparative study. Flavour Fragr. J. 2006, $21,704-712$.

Sample Availability: Samples are available from the authors.

(C) 2010 by the authors; licensee MDPI, Basel, Switzerland. This article is an open access article distributed under the terms and conditions of the Creative Commons Attribution license (http://creativecommons.org/licenses/by/3.0/). 